\title{
LIQUEFACTION SUSCEPTIBILITY MAP OF GREECE
}

\author{
Papathanassiou G. ${ }^{1}$, Valkaniotis S. ${ }^{1}$, Chaztipetros Al. ${ }^{1}$, Pavlides S. ${ }^{1}$ \\ ${ }^{1}$ Aristotle University of Thessaloniki, Department of Geology, 54124 Thessaloniki, Greece, \\ gpapatha@auth.gr
}

\begin{abstract}
The basic goal of this study is the delineation of liquefaction susceptibility zones by correlating geological, geomorphological, seismological and past liquefaction occurrences information. A liquefaction susceptibility map should be used as a screening guide by decision makers for avoiding in advance prone to liquefaction areas. In order to compile this map, we took into consideration published data regarding the surficial distribution of geological units (IGME), the seismic hazard zonation in Greece as it is defined by the Earthquake Palling and Protection Organization and the distribution of historical liquefaction occurrences provided by the relatively database DALO v1.0 http://users.auth.gr/gpapatha/dalo.htm ). Initially, Quaternary age deposits were classified into categories of susceptibility based on their age and depositional process, having considered the designed value of acceleration. Afterwards, areas where past liquefaction occurrences were reported have been upgraded one level. The result obtained by this study is that as very high susceptibility zones are considered the coastal areas at the Ionian Islands and at the Gulf of Corinth
\end{abstract}

Key words: liquefaction, hazard, susceptibility, Greece

\section{Introduction}

Greece shows the highest seismicity in Europe and is considered as one of the most prone to earthquakes countries globally. Thus, it is obvious that earthquake-induced ground failures (landslides, liquefaction etc.) and their effects on the man made environment should be taken into consideration.

Liquefaction is the transformation of saturated, unconsolidated granular material from a solid state to a liquid state as a consequence of increased pore pressures that reduce the effective strength of the material (Youd 1973). The loss of shear strength can cause permanent ground deformations and damage to man-made structures. Therefore, a map showing the prone to liquefaction areas could be used by decision makers and urban planners in order to avoid areas likely to ground failures.

In order to prevent the occurrence of soil liquefaction and to minimize its effects to the man made environment, studies regarding the susceptibility of the geological units should initially take place. Areas susceptible to liquefaction can be identified through detailed geologic, geomorphic and hydrologic mapping (Witter et al. 2006). Afterwards, a prone to liquefaction area should be further investigated in detail in order to evaluate the liquefaction potential and the degree of ground and/or structural failure.

Liquefaction susceptibility maps delineate zones estimated to be liquefiable under given earthquake parameters and have been compiled for several regions and countries including USA, Greece, Japan, 
Iran, Turkey etc. In particular, maps were developed for the San Francisco Bay region (Youd and Perkins 1987; Knudsen and others 1997; Knudsen et al. 2000; Holzer et al. 2002), for Los Angeles urban area (Tinsley et al. 1985), for the region of Thrace, Greece (Papathanassiou et al. 2008) etc. These maps do not predict liquefaction-related ground failures, although ground failures may accompany liquefaction and are more likely to occur in areas with higher liquefaction susceptibility (Tinsley et al. 1985). Moreover, large scale maps, regarding the liquefaction-induced ground disruption, were published for urban areas using data provided by in-situ tests (mainly SPT and CPT). These "microzonation" maps were compiled based on the LPI methodology, suggested by Iwasaki et al. (1978).

The basic goal of this study was the evaluation of the liquefaction susceptibility of geologic units in Greece and a compilation of a map of 1:500.000 scale, using information provided by geologic, geomorphologic and seismic hazard investigations. The information provided by this map should be used only as a screening guide for planning purposes

\section{Geo-engineering evaluation of liquefaction susceptibility}

Several researchers and scientific groups of civil engineers and engineering geologists have studied the liquefaction susceptibility of soil units and proposed criteria for their classification. Brief descriptions of the most used guidelines are presented in this section including the procedures that should be followed for the evaluation of liquefaction susceptibility.

In general, the susceptibility to liquefaction of a geological unit can be evaluated based on its depositional environment; the depositional process affect the liquefaction susceptibility of sediments since fine and coarse grained soils sorted by fluvial or wave actions are more susceptible than unsorted sediments (Youd 1998). In particular, liquefaction susceptibility can be defined based on small scale information and/or data provided by in-situ tests. The former assessment is achieved by collecting data regarding the depositional environment, the age of sediments, the valued of peak ground acceleration and the depth of ground water table and the latter based on detailed information of a soil formation such as the grain-size characteristics and the values of Atterberg limits.

In particular, regarding the regional scale approach, Wakamatsu (1992) classified sedimentary deposits using geomorphological criteria in 3 categories of liquefaction susceptibility under the ground motion at the MMS intensity VIII: likely, possible and not likely. Areas classified as "not likely" liquefaction susceptibility define zones where liquefaction-induced failures are not expected. On the contrary, zones where geomorphological units such as natural levee, former river channel, sandy dry river channel and artificial fill were classified as the highest level of liquefaction potential, i.e. liquefaction likely (TC4 1999). At these areas, further investigation using in-situ test and quantitative parameters of subsoil layers must be performed.

Moreover, another well known procedure for the characterisation of an area as liquefiable was proposed by the California Department of Conservation, Division of Mines and Geology (CDMG 1999). According to these guidelines, a zone is considered as prone to liquefaction when is meeting the following criteria:

- evidence of historical liquefaction occurrences,

— data from in-situ tests and analyses indicate that the soils are likely to liquefy,

in case of lacking of the above data, a site is considered as susceptible to liquefaction when:

- area containing soils of late Holocene age, the groundwater is less 13 meters deep and the peak ground acceleration (PGA) having a 10\% probability of being exceeded in 50 years is greater than $0.1 \mathrm{~g}$, 
- soils of Holocene age where the depth of groundwater table is less than 10 meters and the PGA ( $10 \%$ in 50 years) is greater than $0.2 \mathrm{~g}$,

- areas containing soil deposits of latest Pleistocene age, where the PGA has a 10\% probability of being exceeded in 50 years is greater or equal to $0.3 \mathrm{~g}$ and the depth of the groundwater table is less than 6 meters

A second approach that is followed for the evaluation of liquefaction susceptibility of a soil unit is based on results obtained by laboratory tests, regarding the grain-size characteristics and the values of Atterberg limits of the soil element. In general, sands was believed that were more susceptible than silts or gravel, but laboratory test to fine-grained soils from liquefied soils collected after the earthquakes of Kocaelli and Chi-Chi in 1999, showed that cohesive soils could also liquefied under specific conditions.

In particular, Tsuchida (1971), defined boundaries curves for potentially liquefiable soils based on their grain size distribution curves. Few years later, Wang (1979) and Seed \& Idriss (1982) suggested that the classification of a soil element depends on the Atterberg limits and the percentage of clay-size material. Andrews and Martin (2000) re-evaluated the liquefaction field case histories and transported the "Modified Chinese Criteria" to US conventions. However, recent data (Seed at al. 2003), provided by post-earthquake in-situ tests at liquefied sites triggered by the last two devastating earthquakes of Kocaeli and Taiwan in 1999, indicated that the "modified Chinese criteria" and the liquefaction susceptibility criteria proposed by are considered conservative. Seed et al. (2003) concluded that the plasticity behaviour of fine size particles of soils is more important than the percent clay size, and there are numerous cases of liquefaction with more than $10 \%$ clay-size fines. According to these recommendations, soils with fines content more than $35 \%$ are characterized potentially liquefiable when its liquid limit is less than 37 and the plasticity index is less than 12 (LL $\leq 37$ and PI $\leq 12$ ), and the water content is high relative to their Liquid Limit ( $w_{c}>0.8 \mathrm{LL}$ ). Consequently, fine-grained soils, previous characterized as non-liquefiable based on liquefaction susceptibility criteria proposed by and Andrews and Martin (2000), are now considered potentially liquefiable according to the recommendations of Seed et al. (2003).

\section{Methods}

\subsection{Surficial Geology}

Geologic criteria such as age, depositional environment, relative density, depth to free ground water affect the liquefaction susceptibility of a geologic unit. Understanding the depositional environment and the ages of the geologic units allows the assessment of liquefaction susceptibility. According to Youd (1998) the younger, looser and more segregated the deposit the greater the susceptibility to liquefaction. Older (Pre-Pleistocene) or cemented deposits are almost universally resistant to liquefaction.

In our study, using as a baseline data the geological map of Greece (IGME 1989), we proceed to the digitization of the geological units. Afterwards, the geological units were classified into two categories based on their ages; pre-quaternary and quaternary. This separation was made in order to further analyze and evaluate the liquefaction susceptibility of the deposits of Quaternary sediments since pre-Pleistocene deposits are classified as very low susceptibility units (Youd 1998). The characterization of these sediments had been realized by the Institute of Geological and Mineral Exploration of Greece (IGME 1989) and was adopted in this study.

In particular, as Holocene _1 (latest Holocene age) sediments were grouped the coastal, fluvial, deltaic, marsh deposits: sands, clays, loams, clayely sands usually fine-grained and loose. The presence of a surficial water table (with small seasonal fluctuation of the water-level is one of their char- 


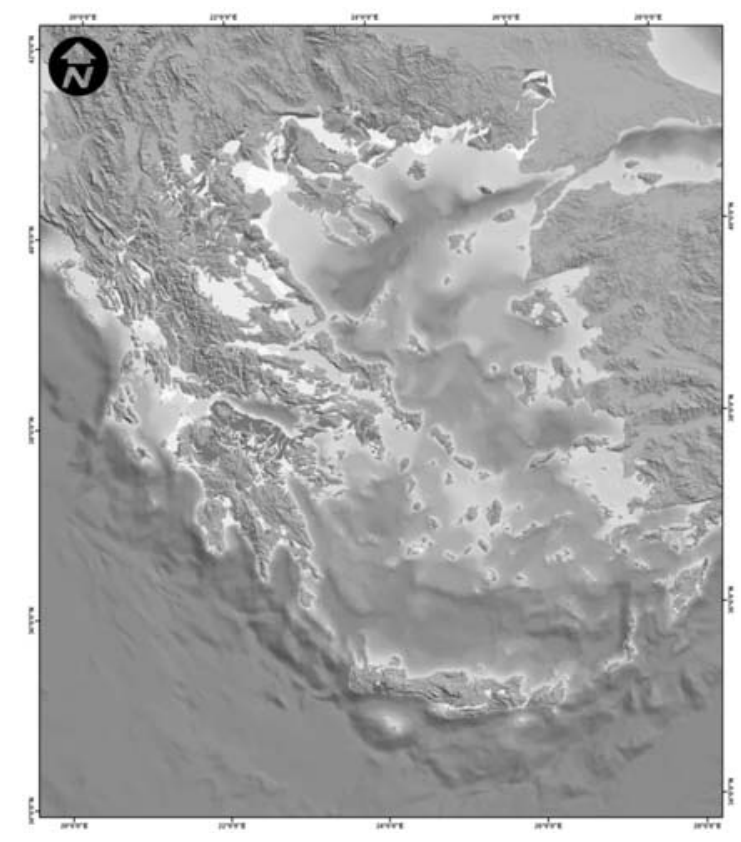

Fig. 1: Geological map of Greece showing the distribution of quaternary sediments (modified from IGME, 1989).

acteristics. Their thickness is about $60 \mathrm{~m}$ approximately.

As Holocene (Holocene age) sediments were characterized recent to present formations mainly consisted of alluvial deposits, fluvial deposits, dunes: sands, clays, sandy or silty clays usually without a surficial water layer. Loose formations and locally slightly cohesive, fine to coarse grained. Their thickness ranges from a few tens of meters, locally exceeding $100 \mathrm{~m}$.

Finally, the Pt (Pleistocene age) sediments include old alluvial deposits, scree, talus cones mainly of Pleistocene age. No surficial water is observed while the thickness is usually around $20 \mathrm{~m}$.

\subsection{Historical liquefaction occurrences in Greece}

Liquefaction is known to occur repeatedly in the same site, thus maps showing the localities of past liquefaction may be considered as potential area of liquefaction in future earthquakes (Youd, 1984). However, lack of evidence does not provide adequate proof that a site is immune to liquefaction (Youd 1988).

In order to identify a detailed map of the distribution of past liquefaction occurrences in Greece, we used the information provided by the published database of DALO v1.0. The Database of historical Liquefaction Occurrences DALO v1.0 (Papathanassiou and Pavlides, 2009) is an open-access file where information regarding liquefaction-induced ground and/or structural deformations is provided. The database was constructed under Ms-Access software and is consisted of six tables and six relative forms. The constructed six tables, used for the introduction of data, are cross-linked by key using elements that are common to several tables, such as the earthquake ID, the failure ID, site ID and reference ID. The independent tables include information regarding the earthquake, the liquefied site, the causative fault, the type of failure, the recorded ground motion and the historical source where the liquefaction-induced failures were described. The presentation of the collected data is accomplished using forms that were decided to be grouped in two main categories. The first 

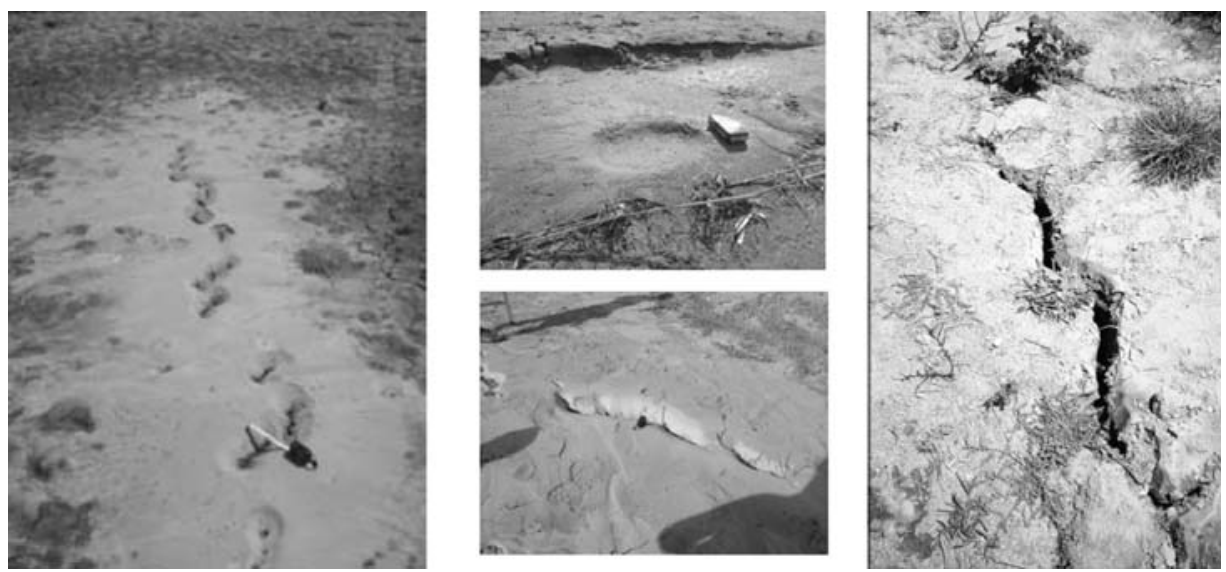

Fig. 2: Liquefaction manifestations in Roupakia, Nidri, Kato Achaia and Alikes, triggered by the events of $8^{\text {th }}$ June, 2008 and $14^{\text {th }}$ August, 2003 in Peloponnesus and Lefkada, respectively.

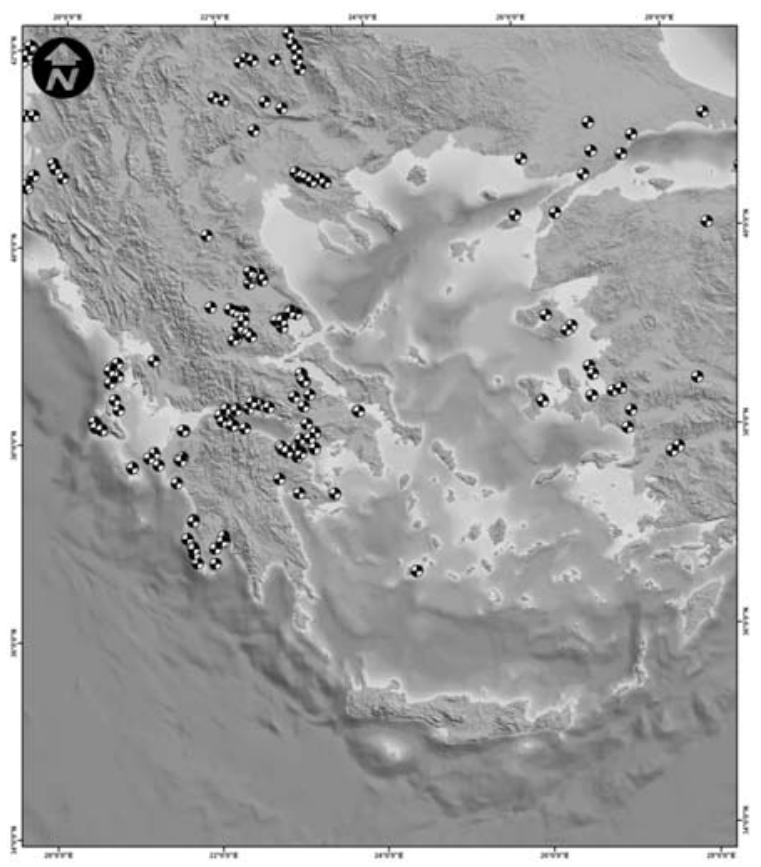

Fig. 3: Map of historical liquefaction occurrences in the broader Aegean region from 1509 AD to $2008 \mathrm{AD}$ (Papathanassiou et al., 2005).

group provides information of earthquake-induced liquefaction characteristics while the second one includes data regarding the liquefied site. The navigation into the database is accomplished by an introductive form which gives to the researcher the opportunity to select one of these two groups for browsing through its contents. Moreover, searching for a specific liquefied site or an earthquake that triggered liquefaction phenomena is now possible and can be achieved by selecting the relative 


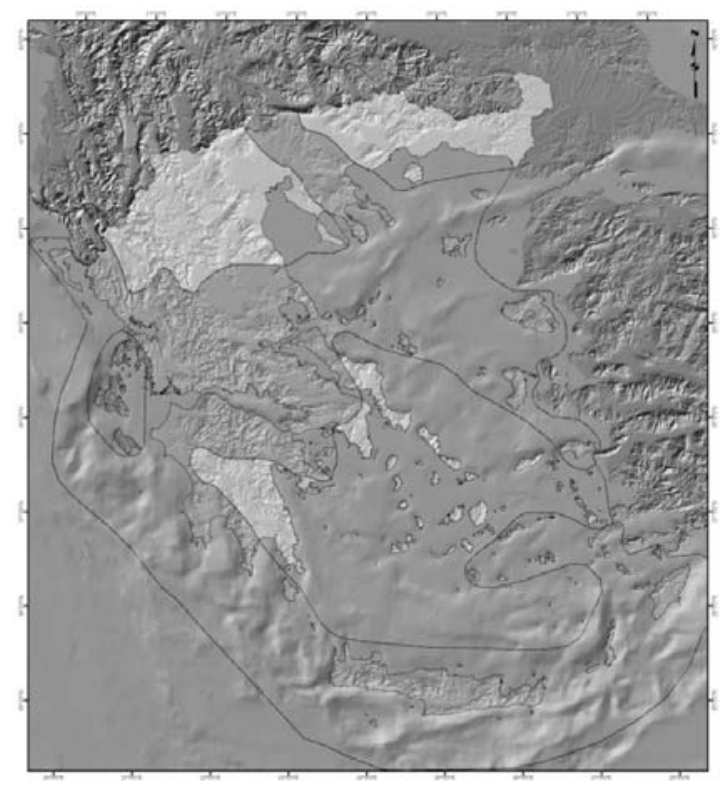

Fig. 4: Seismic hazard zonation of Greece (modified from EAK, 2000)

options, appeared in the menu at the right side of the introductive form. The search is realized using the primary keys of EqID and siteID, respectively and the user can select an earthquake based on the date of occurrence or a liquefied site based on its location.

The first entry in the dataset is in the 16th century AD (Papathanassiou et al., 2005) while the cutoff data for this project is provided by the earthquake-induced liquefaction of June 8th, 2008 in NW Peloponnesus, Greece. However, the oldest event that is mentioned in the seismic catalogues and was correlated to liquefaction-induced failures is the event of 373 B.C. in Eliki (Gulf of Corinth).

A total of 55 earthquakes-induced liquefaction phenomena were introduced into the dataset providing information about 321 cases of liquefaction manifestations. Regarding the areas that were re-liquefied during that period, this study resulted (fig. 3) that they are located mainly at the Gulf of Corinth, the islands of the Ionian Sea and the region of Thessaly (Central Greece).

\subsection{Seismic hazard zonation}

The third criterion that should be examined for the classification of an area as liquefiable is the seismic input. In case of regional scale projects, it is proposed to take into account national hazard maps showing contours of PGA with various probabilities of exceedance (Youd, 1998). In our study, we took into consideration the map provided by the Earthquake Planning and Protection Organisation (EAK, 2000). According to this project, Greece has been divided in three subareas regarding the seismic hazard, where the expected value of PGA, having a 10\% probability of being exceeded in 50 years.

In particular, the first zone delineates areas of low seismicity, mainly in Northern Greece, where the expected PGA is evaluated as $0.16 \mathrm{~g}$ and within the second one the PGA is assigned as $0.24 \mathrm{~g}$. Areas located within the third zone, the Ionian islands and a smaller area in the mainland, were characterized as high seismicity zones where the expected value of PGA is equal to $0.36 \mathrm{~g}$ (fig. 4). 


\section{Defining the liquefaction susceptibility classes}

Taking into account the data describing in the previous section, we proceed to the compilation of the liquefaction susceptibility map of Greece which delineates the areas where liquefaction materials are most likely to exist.

Initially, the categories of susceptibility were assigned based on the geologic (age and depositional environment) characteristics of the sediments and the value of peak ground acceleration that is expected within an area according to Greek Seismic Code. In particular, geologic units characterized as Holocene_1 (latest Holocene age) deposits are classified as Very high, high and moderate susceptibility sediments when they are located in zones where the expected PGA was evaluated as $0.36,0.24$ and $0.16 \mathrm{~g}$ respectively. Geologic units described as Holocene sediments are characterized as high and moderate susceptibility in seismic zones of 0.36 , and $0.24,0.16 \mathrm{~g}$, respectively while the Pt (Pleistocene age) sediments were introduced into the groups of low and very low susceptibility, in areas where the PGA was evaluated as 0.36 and $0.24 \mathrm{~g}$ for the former group and $0.16 \mathrm{~g}$ for the latter one.

Afterwards, we examined the occurrence of historical liquefaction phenomena within an area and we reevaluated the susceptibility of the soil units. In particular, the susceptibility of geologic units where liquefaction phenomena were reported more than once, were upgraded one level. For example, the coastal area at the Gulf of Corinth and the Ionian Islands were upgraded from high to very high susceptibility. Applying the same criterion, areas in Thessaly (Central Greece) were upgraded from moderate to high due to the occurrence of liquefaction manifestations, generated by the events of 1941 and 1954 .

Finally, a total of 5 liquefaction susceptibility categories were assigned to the mapped geologic units based on their geological, seismological and past liquefaction occurrences information and a liquefaction susceptibility map was developed as it is shown in figure 5. These groups consisted of Very high, high, moderate, low and very low susceptibility classes.

\subsection{Categories of liquefaction susceptibility}

In this section are described the classes of liquefaction susceptibility that are proposed by our study. Applying these criteria, the characterization of a geological unit as susceptible to liquefaction or not can be achieved. In particular:

- As Very high susceptibility units are defined the geological units describing sediments of latest Holocene age that are located within areas where the expected PGA is $0.36 \mathrm{~g}$. In addition, latest Holocene and Holocene age deposits located within areas of 0.24 and $0.36 \mathrm{~g}$, respectively and within areas where past liquefaction occurrences were reported are also classified as Very high susceptibility zones,

- As High susceptibility are grouped the geological units included describing sediments of latest Holocene age and Holocene age located within areas where, in some cases, past liquefaction occurrences were reported and where the expected PGA is evaluated as 0.24 and $0.36 \mathrm{~g}$, respectively,

- As Moderate susceptibility the sediments of latest Holocene age and Holocene age located within areas where the expected PGA is evaluated as 0.16 and $0.24 \mathrm{~g}$, respectively,

- As Low susceptibility, the geological units of Pleistocene age within areas where the expected PGA is high $(0.36 \mathrm{~g}$ and $0.24 \mathrm{~g})$ and the occurrence of liquefaction is possible under specific conditions, 


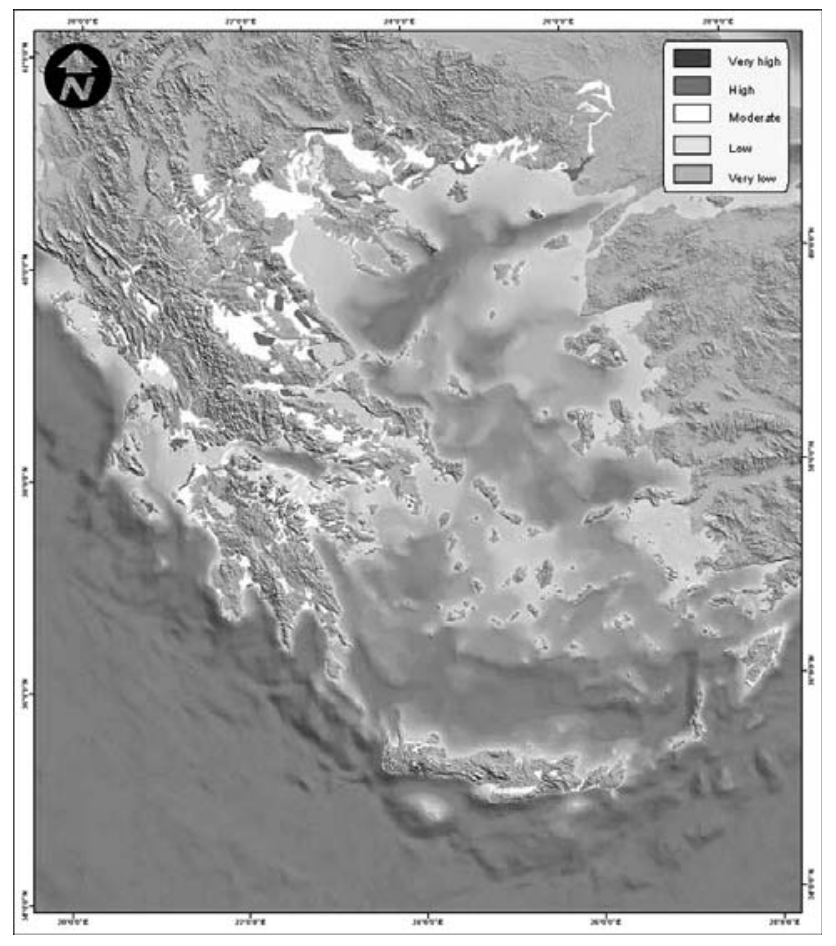

Fig. 5: Liquefaction susceptibility map of Greece.

- And as Very low susceptibility, the sediments of Pleistocene age, located within areas of low seismicity $(0.16 \mathrm{~g})$ where liquefaction isn't expected to be triggered.

\section{Conclusions-Results}

Greece is considered as the most prone to earthquake country in Europe. Therefore, the evaluation of primary and secondary effects triggered by an earthquake is crucial for the avoidance of structural damages. In this study, the procedure that was followed for the compilation of the liquefaction susceptibility map of Greece in scale 1:500.000 is presented. In order to develop this map several criteria were taken into consideration. Initially, data regarding the distribution of geological units and the seismic hazard zonation were collected by published maps and reports. Furthermore, the occurrence of historical liquefaction phenomena was evaluated using the published database of DALO v1.0 and the sites where past liquefaction was reported were plotted as a separate layer and correlated afterwards with the layers of geology and seismic hazard zonation. As a result, the geological units were classified into 5 categories of susceptibility; very high, high, moderate, low and very low. The outcome provided by this study delineates the areas that are susceptible to liquefy. However, in order to evaluate the liquefaction potential of an area detailed investigations are required.

\section{References}

Andrews, D.C., and Martin, G.R., 2000. Criteria for liquefaction of silty sands, In: $12^{\text {th }}$ World Conference on Earthquake Engineering, Auckland, New Zealand 
EAK, 2000. Greek Seismic Code, OASP, Athens, 72 pp and 7 Appendixes

CDMG, 1999. Guidelines for analyzing and mitigating liquefaction hazards in California, California Department of Conservation, Division of Mines and Geology, Special Publication 117, p. 63

Holzer, T.L. Bennett, M.J., Noce, T.E., Padovani, A.C., Tisnley, J. C. III., 2002. Liquefaction hazard and shaking amplification mpas of Alameda, Berkeley, Emeryville, Oakland, and Piedmont, California: A digital database. U.S. Geological Survey Open File Rep. 02-296 (version 1.0), U.S. Geological Survey, Menlo Park, Calif., (http://geopubs.wr.usgs.gov/open-file/of02-296 )

IGME. 1989. Seismotectonic map of Greece, 1:500000 scale

Iwasaki, T., Tatsuoka, F., Tokida, K., Yasyda, S., 1978. A practical method for assessing soil liquefaction potential based on case studies at various sites in Japan. Proceedings. 2nd Int. Conf. on Microzonation, San Francisco, 2, 885-896

Knudsen, K.L., Lettis, W.R., 1997, Preliminary maps showing Quaternary geology of twenty 7.5-minute quadrangles, eastern Stockton, California, 1:100,000 quadrangle: National Earthquake Hazards Reduction Program, U.S. Geological Survey, Final Technical Report, Award \#1434-94-G-2499.

Knudsen, K.L., J.M. Sowers, R.C. Witter, C.M. Wentworth, E.J. Helley, 2000, Preliminary Maps of Quaternary Deposits and Liquefaction Susceptibility, Nine-County San Francisco Bay Region, California: A Digital Database, U.S. Geological Survey Open-File Report 00- 444. Digital Database by Wentworth, C.M., Nicholson, R.S., Wright, H.M., and Brown, K.H. Online Version 1.0.

Papathanassiou G, Pavlides S, Christaras B, Pitilakis K (2005) "Liquefaction case histories and empirical relations of earthquake magnitude versus distance from the broader Aegean Region, Journal of $\mathrm{Ge}$ odynamics, 40, 257-278

Papathanassiou G., Valkaniotis S., Pavlides Sp, 2008. Geo-engineering mapping with respect to liquefaction susceptibility of the region of Thrace, North-eastern Greece, Proceedings of the 31 st General Assembly of the European Seismological Commission ESC 2008 Hersonissos, Crete, Greece, 7-12 September 2008

Papathanassiou G,. and Pavlides Sp., 2009. GIS-based DAtabase of historicalLiquefaction Occurrences in broader Aegean region, DALO v1.0, Proceedings of the EarthquakeGeotechnical Engineering Satellite Conference XVIIth International Conference on Soil Mechanics \& Geotechnical Engineering 2-3. 10.2009, Alexandria, Egypt

Seed H.B., and Idriss, I.M., 1982. Ground motion and soil liquefaction during earthquakes, monograph, EERI, Oakland, $\mathrm{Ca}, 134 \mathrm{pp}$.

Seed, R.B., Cetin, O.K., Moss, R.E.S., Kammerer, A.M., Wu, J., Pestana, J.M., Riemer, M.F., Sancio, R.B., Bray, J.D., Kayen, R.E., Faris, A., 2003. Recent advances in soil liquefaction engineering: a unified and consistent framework, 26th annual ASCE L.A. Geot. Spring Sem., Long Beach, California, April 30, $71 \mathrm{pp}$

TC4, 1999. Manual for zonation on seismic geotechnical hazards (revised version), Technical Committee of Earthquake geotechnical engineering ISSMGE, pp. 219

Tinsley, J.C., Youd, T.L., Perkins, D.M., Chen, A.T.F, 1985, Evaluating Liquefaction Potential, in Ziony, J.I., ed., Evaluating earthquake hazards in the Los Angeles Region - an earth science perspective: U.S. Geological Survey Professional Paper 1360, 263-316.

Tsuchida, H., 1971. Estimation of liquefaction potential of sandy soils, Proceedings of the $3^{\text {rd }}$ Joint Meeting, US-Japan, UNJR

Youd, T.L., 1973. Liquefaction, flow and associated ground failure: U.S. Geological Survey Circular 688, $12 \mathrm{pp}$.

Youd T.L (1984) Recurrence of liquefaction at the same site, Proceedings of the 8th World Conference 
on Earthquake Engineering, 3, 231-238

Youd, T.L., 1998. Screening guide for rapid assessment of liquefaction hazard at highway bridge site, Technical report MCEER-98-0005, 58 pp.

Youd, T.L., Idriss, I.M., 1978. Mapping of liquefaction induced ground failure potential, J. Geotech Eng Div., ASCE, 117, 1, 35-50

Youd, T.L., Perkins, D.M., 1987. Mapping of Liquefaction Severity Index, J. Geotech Eng Div, ASCE, $113,11,1374-1392$

Youd, T.L., Idriss, I.M., Andrus, R.D., Arango, I., Castro, G., Christian, J.T., Dobry, R., Finn, W.D.L., Harder, L.F., Hynes, M.E., Ishihara, K., Koester, J.P., Liao, S.S.C., Marcurson, III WF, Marti, G.R., Mitchell, J.K., Moriwaki, Y., Power, M.S., Robertson, P.K., Seed, R.B., Stokoe II K.H. 2001 . Liquefaction resistance of soils: summary report from the 1996 NCEER and 1998 NCEER/NSF workshops on evaluation of liquefaction resistance of soils, J. Geotec. Geoenv. Eng., 817-833

Wang, W., 1979. Some findings in soil liquefaction, Research report, water conservancy and hydroelectric power scientific research institute, Beijing, August.

Wakamatsu, K., 1992. Evaluation of liquefaction susceptibility based on detailed geomorphological classification, Proceedings of the Technical Papers of Annual Meeting Architectural Institute of Japan, B, 1443-1444 (in Japanese)

Wakamatsu K,. 1993. History of Soil liquefaction in Japan and Assessment of Liquefaction Potential based on Geomorphology, PhD Thesis, Waseda University Tokyo, Japan, 245pp.

Witter, C.R., Knudsen, L.K., Sowers, M.J., Wentworth, M.C., Koehler, D.R., Randolph, C.E., 2006. Maps of Quaternary Deposits and liquefaction susceptibility in the Central San Francisco Bay Regio, California, Open file report 2006-1037, USGS, pp. 43 